\title{
CYTOLOGICAL INDICES IN CHILDREN WITH GINGIVITIS
}

\author{
Melnyk V. S., Horzov L. F. \\ Uzhhorod National University, Ukraine
}

\begin{abstract}
Development of gingivitis in children with fixed orthodontic appliances (FOA) is an urgent problem of today's periodontology, requiring elaboration of new methods that would give an opportunity not only to diagnose but also to predict the course of periodontitis in a given population. The investigation was conducted in patients with catarrhal and hypertrophic gingivitis during the treatment by FOA. It was established that cellular composition of gum mucosa undergoes cytosospecific alterations, which is manifested by qualitative changes of gingival epitheliocytes. In this case the indices of pathological shift point to the clinical and morphological form of the diagnosed inflammatory process in the gums. Conclusion. The maximal intensity of the inflammatory process in the gums takes 3 months of using FOA while the cytological criteria in this observation period are the functional state of segmental leukocytes and the alterative changes of intermediate cells in the form of foamy cytoplasm in children with catarrhal gingivitis. In children with hypertrophic gingivitis cytological adjustment indices are destructive changes in the epithelial cells, which manifests itself as the appearance of the naked core elements and signs of necrobiosis against the background of a large number of segmental leukocytes.
\end{abstract}

Keywords: gingivitis, epithelial cells, fixed orthodontic appliances, cytological indicators, children.

Introduction. Today, the intensity and prevalence of periodontal tissue diseases during the treatment with fixed orthodontic appliances increases, which is confirmed by a large number of studies [1-5].

The cytological method of research makes it possible noninvasively and in a short time to diagnose the presence and nature of pathological changes that occur in the gums, track the dynamics, objectivize the effectiveness of treatment and predict long-term results [6-8].

2. PURPOSES, SUBJECTS and METHODS:

2.1 Purpose: The aim of our research is to determine the cytological criteria for prognosis of clinical course of gingivitis in children with fixed orthodontic appliances and to examine the gums epithelium.

\subsection{Subjects \& Methods}

The material was collected from the surface of the marginal part of the gums and cheeks at $1.5 \mathrm{~cm}$ below the teeth closure by scraping with

Corresponding Author:

Ludmyla Horzov, MD, PhD, Associate Professor

of the Department of Pediatric Dentistry.

Uzhhorod National University, Ukraine.

E-mail: liudmyla.horzov@uzhnu.edu.ua a serpentine styler. Subsequently, the collected material was applied to a sterile objective glass. Drying of the material was carried out by dry fixation at room temperature, under the conditions of open access of air, with subsequent coloring. The principle of the combined coloring of the latchdye of May-Grunwald and the dye of HimzaRomanovsky provides a coherent picture for the differentiation of the components of the epithelial cells. The pebbles were placed in a container and lowered into a dye-retaining cup [9-12].

It was fixed for 5 minutes, washed with water and stained with an aqueous solution of Romanovsky dye $(10 \mathrm{ml}$ of dye per $100 \mathrm{ml}$ of distilled water), after which the glass was washed with water and spread out to a stand for drying. The analysis of the cytograms was carried out using Micros-50 microscope (Austria), using magnification of 1000. Planning and testing of cytological methods of the investigation and its implementation were carried out according to legal acts and ethical norms and requirements for scientific morphological research [13-15].

The study implied a detailed morphological analysis of the gum cell composition of 59 children with inflammatory diseases of periodontal tissues. The patients were divided into two groups depending on the diagnosed clinico-morphological 
form of gingivitis. The first group consisted of 33 children who had generalized catarrhal gingivitis with FOA (fixed on the lower jaw). The second group included 26 children with chronic generalized hypertrophic gingivitis (granulating form) in the treatment of FOA (fixed on the lower jaw). The control group comprised 28 persons of the corresponding age, without accompanying somatic pathology with an intact periodontal disease. In order to assess the pattern of cellular changes, the materials for cytological examination in Groups 1 and 2 were taken on the $3^{\text {rd }}$ and $12^{\text {th }}$ months of the FOA treatment.

We received written consent from patients to conduct research that met the ethical requirements [16].

\section{Conflict of interests}

There is no conflict of interests.

\section{RESULTS AND DISCUSSION}

The cell composition of the gums in the control group of the children at Himza-Romanovsky staining is represented by intermediate and superficial cells, as well as horny scales. The cytological organization of intermediate epithelial cells reflects the regional features of the anatomical site. The form of cells is mostly irregular, or elongated, the cytoplasm is weakly basophilic, less eosinophilic, with wellcharacterized nucleus of round or oval shape. Plasma cell has many wrapped edges. Surface epithelial cells are characterized by a hexagonal form and a decrease in the nuclear-cytoplasmic ratio toward the nucleus. The nuclei are mostly dense, with color sharply hyperchromic. It should be noted that the cells are located mainly in clusters (Fig. 1).

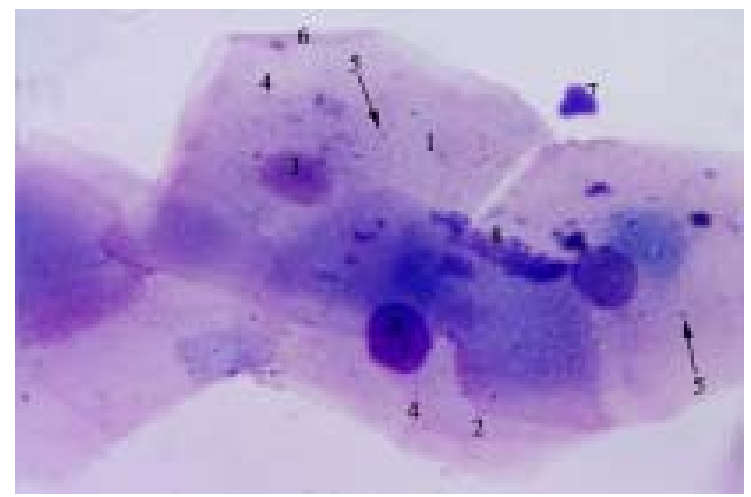

Fig. 1. Cellular composition of gum mucosa. Himza-Romanovsky staining. Magnification: $\times 100$, approx. $\times 10$ : 1 -intermediate epithelial cell; 2 - superficial epitheliocytes; 3 - nucleus;

4 - cytoplasma; 5 - single azur-pozitive granules; 6-wrapped edge plasmolemma;

7 - segmental leukocyte; 8 - microflora
It is worth noting the presence of segmented leukocytes in the cellular composition. They are single, located mainly on the periphery of the epithelial cells. The presence of these type of cells provides the basis for protection of gums from the influence of microbial factor, which was visualized in insignificant quantities and contaminated the intermediate and superficial epithelial cells. Most of horn flakes have hexagonal shape, the cytoplasm is usually weakly basophilic, with a central location of the contours of the nucleus that was lost in the process of differentiation of the epithelial cell. Perinuclear space is surrounded by tonefilament inclusions, which form a mesh structure. Granules of keratogialin are stored, which confirms the phatism in the mechanisms of gingival germination, by orthoceratosis (Fig. 2).

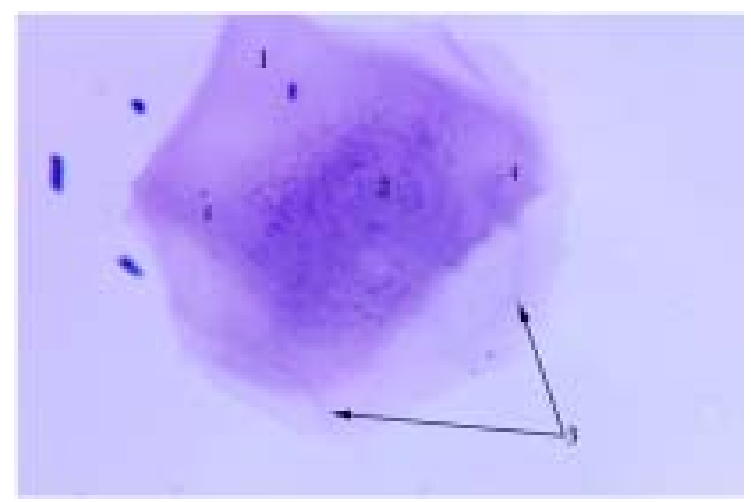

Fig. 2. Cellular composition of gum mucosa in control group children. Himza-Romanovsky staining. Magnification: $\times 100$, approx. $\times 10$ :

1 - horny scales; 2 - nucleus shadow; 3 - inclusion of tonofilaments; 4 - granules of keratogialin

The peculiarity of the cellular composition of the gums in the control group of children was the absence of basal and parabasal epitheliocytes, as well as, in most, hematogenous cells. Only in isolated epithelial cells, the signs of destruction in the form of disturbances in the clarity of the plasmolemic contours were utilized. Consequently, the above-mentioned tinctorial characteristics of the gingival epitheliocytes characterize the functioning of the gum defense mechanisms in the normal manner, thereby providing homeostasis to the gum mucosa. In this case, the components that take an active part in phagocytosis and protect the tissues under conditions of microbial influence, however, play the role of the immune link in the cascade of pathogenetic mechanisms of damage to periodontal tissues. The cellular composition of 
gums in the first group of children for 3 months of use of FOA was characterized by the presence of intermediate and superficial epitheliocytes and horny scales. Most of the intermediate cells had a stereotypical organization relative to this class of cells in the control group, but there were signs of cytological rebuilding in epitheliocyte section. They have become smaller in size by reducing the volume of the cytoplasm, the nucleus are partially optically light with scattered lumps of chromatin. The cytoplasm has a foamy organization. The peculiarity of the cellular composition of the gums for this observation period was the presence of hematogenous cells, in particular, a large number of neutrophilic granulocytes at different stages of phagocytosis, with clearly segmented nucleus, without junctions between segments. It should be noted that this type of cells was visualized regardless of the clinical-morphological form of gingivitis, but their functional status changed. In the conditions of chronic flow, segmental neutrophil granulocytes form cell clusters. In this case, the cell contours are clearly visualized and the nucleation segmentation is maintained. Intensive contamination, predominantly coca flora, has undergone interim epitheliocytes in the form of chain and semi-circular figures at this time of observation. Horny scales were visualized in a significantly smaller number, compared to their quantitative composition in the control group. They are mostly eosinophilic, polygonal, characterized by the absence of clear contours and obsession (Fig. 3).

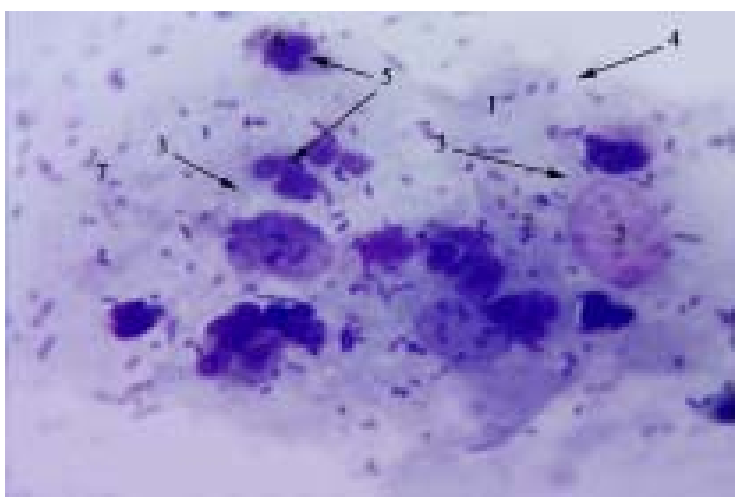

Fig. 3. Cellular composition of gum mucosa in Group 1 on the 3rd month of NOA administration. Himza-Romanovsky staining. Magnification: $\times 100$, approx. $\times 10$ :

1 - intermediate epithelial cell; 2 - an optically light nucleus; 3 - foame cytoplasm;

4 -plasmolysis emulation; 5-segmental leukocyte; 6 - segments of the the leucocyte; 7 - microflora
The analysis of the results of the research shows that for 3 months using FOA, the cellular composition of the gum undergoes a qualitative adjustment, with the cytomorphorphological pattern, due to the presence of segmental neutrophilic leukocytes, reflects catarrhal inflammation, against the background of abnormal erythema of the epithelial plate as a decrease in the activity of maturation processes and differentiation of epithelial cells to terminal stages. The appearance of cells with foamy cytoplasm is a consequence of the damaging effect of the gingival epithelium, which is accompanied by a pronounced cellular alteration and naturally accompanied by the presence of chronic inflammatory process in the gums. The cellular composition of the gums of the children of the first group for 12 months using FOA was characterized by the presence of intermediate, superficial epitheliocytes and horny scales. Intermediate cells had a stereotypical organization regarding this class of cells in control group of the children. However, it is quite interesting to note that, for the time of observation of qualitative rearrangement, superficial epitheliocytes have been exposed, in the form of elements of cytopathology. By evidence of varying frequency, depending on the intensity of the inflammatory process in the gums, there are dystrophic changes, namely the cytoplasmic vacuolation. It should be noted that the vacuolation has very hydrophilic character. Hydrophobic vacuoles are abundant, they are large in size and perinuclear. Small vacuoles are located mainly at the poles of superficial epitheliocytes. Cell nucleus of this class are hyperchromic and picnographic. It should be noted that the feature of the cellular composition of the gum at this time of observation is the presence of single macrophages that were in rest, had an elongated shape and an optically dense core. In the cytoplasm of the cell data, lysosomes are visualized. In addition to phagocytic function, this type of cells initiates the presentation of microbial agents to their lymphocytes. Also, it should be noted that along with the main function - phagocytosis and enzymatic cleavage of microbial factors, their availability is explained by the ability to secrete a number of biologically active substances and cytokines, and as a consequence, the proliferative and control function of cell data, which makes it possible to create a bar of the immune competent cell for further progression of the inflammatory process (Fig. 4).

Thus, changes in the cellular composition of the gum on the 12th months of using FOA is a 


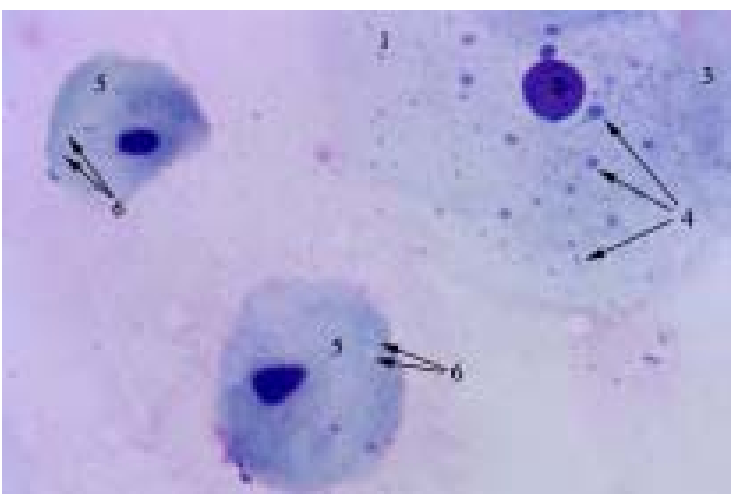

Fig. 4. Cellular composition of gum mucosa in Group 1 on the $12^{\text {th }}$ month of NOA administration. Himza-Romanovsky staining. Magnification: $\times 100$, approx. $\times 10$ :

1 - superficial epitheliocyte; 2 - nucleus;

3 - cytoplasm; 4 - vacuoles; 5 - macrophage; 6 - lysosomes

manifestation of the protective and adaptive reaction of the gum mucosa to the effect of FOA and the microbial factor, directed on delimitation and phagocytosis. And as an indicator of pathological shift in the characterization of the cellular composition of the gingival epithelium in children with chronic catarrhal gingivitis, cells with signs of vacuolic dystrophy stand against the background of the use of FOA. The cellular composition of the gums of Group 2 children for 3 months of FOA administration was characterized by the presence of intermediate, superficial epitheliocytes and horny scales. It should be noted that the number of cells and horny scales that are in the terminal stages of differentiation has decreased, compared with the control group. In our opinion, the shift of the cellular composition toward less differentiated forms of epithelial cells is associated with an increase in the proliferative activity of basal and parabasal cells, which is confirmed by the results of complex histological researches. The latter suggests that the use of FOA initiates the activation of mechanisms that prevent the maturation of epithelial cells gums until the terminal stages. Qualitative rearrangement has undergone a part of intermediate epitheliocytes, in the form of loss of clarity of plasmolars and urazation. Optical nucleus with diffused lumps of heterochromatin. The organization of most intermediate cells is also stereotyped. However, in the part of the intermediate epithelial cells, a cytospecific reorganization is determined. Among them, epithelial cells are visualized with signs of non-fibrotic changes. Quite often, the alkaline nucleus of intermediate epithelial cells were visualized. In our opinion, the bare nucleus of the cell in the form of chromatin breasts reflect the activity of the processes of phagocytosis of microorganisms that occur in cells and indicates the activity of phagocytic reaction, which includes the cytoplasmic enzymatic hydrolysis of bacteria. The peculiarity of the cellular composition of the gums in this observation period is the presence of a large number of segmental neutrophilic leukocytes, among which part the lysed and concentrated on the periphery of the epithelial clusters. Attention is drawn to intensive microbial population, among which the rods and cocci were dominated by representatives. Also, it stands to mention the presence of lymphocytes. The cytoplasm of the latter was characterized by basophilia, acquiring a light blue color and surrounding the nucleus in the form of a narrow border. The cytoplasm visualized the perinuclear zone. The presence of lymphocytes in our opinion, reflects the tension of the humoral chain of the immune system and confirms the results of complex histological studies of predecessors regarding the involvement of the immune system and the chronization of the process (Fig. 5).

By analyzing the cellular composition of gums in Group 2 children on the $3^{\text {rd }}$ month of FOA administration, we can conclude that unlike control and Group 1 children, epitheliocytes of the gums are subject to a greater degree of destruction, which is manifested by the appearance of gloatuclear elements and signs of necrobiosis of epithelial cells. Cellular gums in Group 2 children

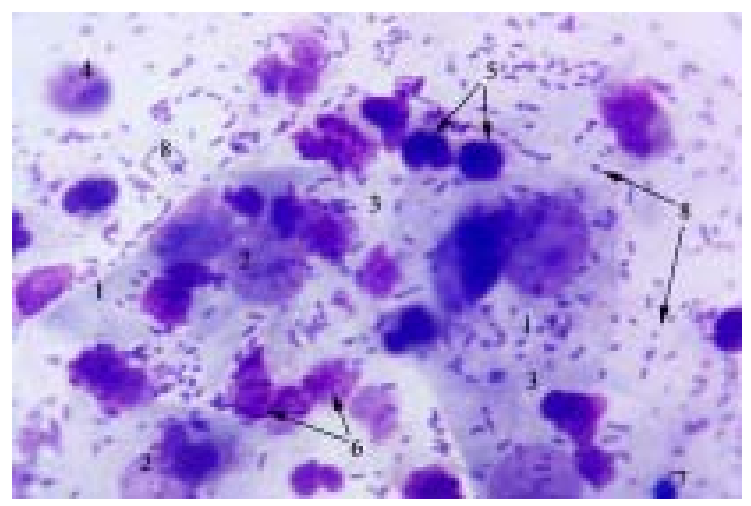

Fig. 5. Cellular composition of gum mucosa in Group 2 on the 3rd month of NOA

administration. Himza-Romanovsky staining. Magnification: $\times 100$, approx. $\times 10$ :

1 - intermediate cell with signs of necrobiosis; 2 - the nucleus of intermediate cell;

3 - cytoplasm; 4 - naked core; 5 - segmental neutrophilic leukocytes; 6 -neutrophilic leukocytes in the stage of lysis; 7 - lymphocyte; 8 - microflora 
on the $12^{\text {th }}$ month of FOA using was stereotyped and characterized by the presence of intermediate, superficial epitheliocytes and horny scales with a steady tendency to reduce the epithelial cells of terminal stages of diferon. The feature of the cellular composition of the gums at this time of observation was the presence of epithelial cells with signs of irritation. Visualized cells belong to superficial epitheliocytes and differ from the stereotypical class of these cells in smaller and sharply expressed basophilia of the cytoplasm. This makes it possible to suggest that in the case of hypertrophic gingivitis, mechanisms of violation of the desquamation processes of the epithelium, which provide the barrier function of the gums, due to the polymorphocyte infiltration of their own plate, are started in the background of the use of the FOA. The presence in the cellular composition of the lymphocytes confirms this assumption. The latter were characterized by basophilia of the cytoplasm, which surrounds the hyperchromatic nucleus in the form of a narrow border. The cytoplasm visualized the perinuclear zone (Fig. 6).

The indicated changes of cellular gum composition on the $12^{\text {th }}$ month of FOA using are the result of violation of differentiation of different forms of epithelial cells, initiated by inflammatory infiltrates of own plate. Thus, it has been established that the main component of the cellular composition is gum in the control group of children, and the first and second groups of observations are cells of the multilayered flat epithelium. They are present in the cellular composition, both in normal state and in pathology. It should be noted

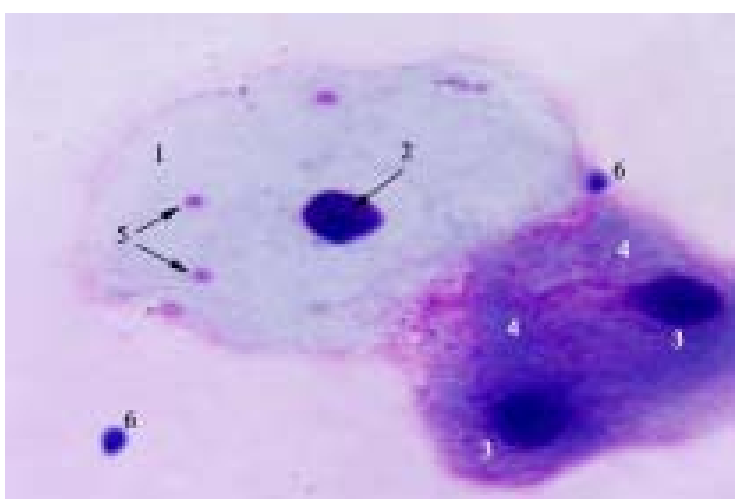

Fig. 6. Cellular composition of gum mucosa in Group 2 on the 12th month of NOA administration. Himza-Romanovsky staining. Magnification: $\times 100$, approx. $\times 10$ :

1 - superficial cell; 2 - the pyknotic nucleus;

3 - epithelial cells with signs of irritation; 4 - sharply basophilic cytoplasm of superficial epitheliocutes; 5 - granules of keratogialin; 6-lymphocyte that the cells of the flat epithelium are heterogeneous, which reflects the heterogeneity of cells of the epithelial cover of the gums. On the background of the use of non-removable orthodontic appliances, the cellular composition of the gum undergoes a qualitative rearrangement, both in the epithelial and in the connective tissue component. The information above shows the violation of processes of differentiation of the gums epithelium as a result of the inflammatory process against the background of the use of FOA.

Discussion. The results obtained in this study are in agreement with previous studies and indicate that the above changes cause violation of differentiation processes epithelium gums in the result of the inflammatory process against the background of the use of FOA [17].

These provisions provide further development in the course and agree with the basic developments on the peculiarities of the cytological organization of gums in normal state and in inflammation [18-19]. Some differences are due to age-standardized aspect [20].

\section{Conclusions}

Cellular composition of the mucous membrane of the gums during the treatment by FOA that provide a cytosolic rebuilding, which manifests itself in qualitative changes of gingival epitheliocytes. In this case, indices of pathological shift justify the clinical and morphological form of the diagnosed inflammatory process in the gums. The maximal intensity of the inflammatory process in the gums takes 3 months of FOA using, while the cytological criteria in this observation period are the functional state of segmental leukocytes and the alterative changes of intermediate cells in the form of foamy cytoplasm in Group 1 children. In Group 2 children, in the given period of observations, cytological adjustment indices are destructive changes in the epithelial cells, which manifests itself as the appearance of the naked core elements and signs of necrobiosis against the background of a large number of segmental leukocytes. On the $12^{\text {th }}$ month of FOA administration both groups of children were found to have reorganization of cellular composition characterized by signs of sustained dystrophic changes in epithelial cells, indicated by cells with signs of dystrophy and nonfibrotic changes. The above changes cause the violation of processes of differentiation of the gums epithelium as a result of the inflammatory process against the background of FOA administration. 


\section{References}

1. Kornman K, Van Dyke T: (2008) Inflammation and factors that may regulate inflammatory response. J Periodontol 79, 1313-1326 [PubMed]

2. Van Dyke T, Kornman K: (2008) Bringing light to the heat: "Inflammation and periodontal diseases: A reappraisal". J Periodontol 79, 1503-1507 [PubMed]

3. Hasyuk N. V., Khudyakova M. B. (2013) Kliniko-morfolohichni zminy v yasnakh u khvorykh na khronichnyy hipertrofichnyy hinhivit [Clinical and morphological changes in gums in patients with chronic hypertrophic gingivitis] Visnyk problem biolohiyi ta medytsyny, no 1, pp. 265-268.

4. Hasyuk P. A., Hasyuk N. V. (2014) Osoblyvosti morfolohichnoyi budovy yasen u normi ta pry khronichnykh hinhivitakh : navch. posibnyk [Features of morphological structure of gums in norm and at chronic gingivitis: teaching. manual]. Ternopil': Ukrmedknyha, $91 \mathrm{p}$.

5. Kornman K. (2008) Mapping the pathogenesis of periodontitis: A new look. J Periodontol 79, 1560-1568 [PubMed]

6. Lamster I, Ahlo J. (2007) Analysis of gingival crevicular fluid as applied to the diagnosis of oral and systemic diseases. Ann N Y Acad Sci 1098, 216-229 [PubMed]

7. Faggion C, Petersilka G, Lange D, Gerss J, Flemmig T. (2007) Prognostic model for tooth survival in patients treated for periodontitis. J Periodontol 31, 226-243 [PubMed]

8. Evans R, Klausen B, Sojar H, Ramamurthy N, Evans M, Genco RJ. (1994) Molecular pathogenesis of periodontal disease. Am Soc Microbiol 38, 267-278.

9. Bykov V. L. (2014) Gistologiya i embrionalnoye razvitiye polosti rta cheloveka: uchebnoye posobiye [Histology and embryonic development of the human oral cavity: a textbook]. "GEOTAR-Media",624 p.

10. Salyuk O. D. (2002) Kompleksnyy podkhod k otsenke tsytolohycheskoho sostoyanyya desen pry ranney dyahnostyke hynhyvyta [Complex approach to the evaluation of the cytological condition of the gums in the early diagnosis of gingivitis] Sovremennaya stomatolohyya, no 1, pp.17-20.

11. Khusaynova Y. S., Varvuleva Y. Yu. (2007) Otsenka tsytolohycheskykh pokazateley bukkal'noho epyteliya dlya dyahnostyky funktsyonal'noho sostoyanyya cheloveka [Evaluation of cytological parameters of buccal epithelium for diagnosis of a person's functional state]. Klynycheskaya laboratornaya dyahnostyka, no 3, pp. 10-11.

12. Lutsenko M. T. (2011) Tsytofyzyolohyya: [praktycheskoe rukovodstvo] [Cytophysiology: [practical guidance]. Novosybyrsk - Blahoveshchensk - $216 \mathrm{p}$.

13. Grigoryan A. S., Grudyanov A.I. (2001) Klyuchevyye zvenia patogeneza zabolevaniy parodonta $\mathrm{v}$ svete dannykh tsitomorfometricheskogo metoda issledovaniya [Key links in the pathogenesis of periodontal diseases in the light of the data of the cytomorphometric method of investigation]. Stomatologiya, no 1, pp. 5-8.

14. Grudyanov A. I., Zorina O. A. (2009) Metody diagnostiki vospalitelnykh zabolevaniy parodonta [Methods of diagnosing periodontal inflammatory diseases] "MIA", $109 \mathrm{p}$.

15. Korchagina E. A., Grinin V. M., Tkachenko T. B. (2008) Neinvazivnyye metody issledovaniya v otsenke vozrastnykh osobennostey slizistoy obolochki polosti rta [Noninvasive methods of research in assessing the age-related features of the oral mucosa] Stomatologiya dlya vsekh, no 4, pp. 14-16.

16. Mishalov V. D. Chaykovs'kyy Yu. B., Tverdokhlib I. V. (2007) Pro pravovi zakonodavchi ta etychni normy y vymohy pry vykonanni naukovykh ta morfolohichnykh doslidzhen' [On legal legal and ethical norms and requirements in carrying out scientific and morphological researches]. Morfolohiya, no 2, pp.1-5.].

17. AndjeliжJ, MatijeviжS. (2014) Condition of periodontium in patients with fixed orthodontic appliances. Vojnosanit Pregl., 71(10), 915-9.

18. Hasiuk P, Hasiuk N, Kindiy D, Ivanchyshyn V, Kalashnikov D, Zubchenko S. (2016) Characteristics of cellular composition of periodontal pockets. Interv Med Appl Sci., 8(4),172-177.

19. Kumar A, Masamatti SS, Virdi MS. (2012) Periodontal diseases in children and adolescents: a clinician's perspective part 2. Dent Update. 39(9):639-42, 645-6, 649-52.

20. Alrayyes S., Hart T.S. (2011) Periodontal disease in children. Dis. Mon., 57(4),184-191.

Received: 19-Dec. - 2017

Accepted: 17-Apr. - 2018 